\title{
El procesamiento de imágenes de impacto por la audiencia de informativos de televisión
}

\author{
Samia BenAissa PEDRIZA \\ Universidad Complutense de Madrid \\ samiabenaissa@hotmail.com
}

Recibido: $07 / 05 / 2012$

Aceptado: 28/11/2012

\begin{abstract}
Resumen
Un estudio practicado entre sesenta voluntarios revela que el procesamiento de información audiovisual en noticias elaboradas con imágenes de impacto emotivo depende de factores como el grado de coordinación entre los códigos audiovisuales o el uso de técnicas de recapitulación de datos como los titulares. Un alto grado de coordinación entre la narración y las imágenes impactantes no garantiza ni un mejor recuerdo ni una mejor comprensión de información en todos los casos. Noticias con un grado más bajo de correspondencia entre códigos audiovisuales son mejor comprendidas y recordadas cuando se incluyen imágenes de naturaleza llamativa. La audiencia de televisión recuerda y comprende en mayor medida la información verbal presentada con anterioridad y posterioridad a la emisión de unas imágenes de impacto. Palabras clave: imágenes impactantes, imágenes llamativas, coordinación de códigos audiovisuales, recuerdo de información audiovisual, comprensión de información audiovisual.
\end{abstract}

\section{Understanding and Recall of Bad News Pictures by TV Viewers}

\begin{abstract}
A sixty participant survey reveals that learning and recall of information in bad news is directly related to the degree of text-picture correspondence as well as to the use of bumpers and recaps. Strong audiovisual redundancy in negative news not always fosters upper levels of recall and comprehension. News with lower text-picture correspondence reach higher ranks of recall and grasp when arousing visuals are used. TV viewers tend to recall and understand better verbal information shown before and after the release of bad news pictures.
\end{abstract}

Keywords: bad news pictures, arousing visuals, text-picture correspondence, audiovisual information recall, audiovisual information comprehension

\section{Referencia normalizada}

BENAISSA PEDRIZA, Samia (2013): "El procesamiento de imágenes de impacto por la audiencia de informativos de televisión". Estudios sobre el mensaje periodístico. Vol. 19, Núm. 1, págs.: 331-346. Madrid, Servicio de Publicaciones de la Universidad Complutense.

Sumario: 1. Introducción. 2. Fuentes y metodología. 3. Imágenes de impacto y coordinación entre códigos audiovisuales. 4. El uso de imágenes de impacto en rótulos y titulares. 5. La comprensión de información en presencia de imágenes de impacto. 6. Conclusiones. 7. Referencias bibliográficas.

\section{Introducción}

El uso habitual de imágenes de alto impacto emotivo en los informativos de televisión es una práctica común en los programas de noticias de principios del siglo XXI. Desde el último cuarto del siglo XX asistimos a un cambio comunicativo en las sociedades desarrolladas del mundo occidental que ha dado lugar a una serie de fenómenos mediáticos de relevancia periodística como el denominado infoentretenimiento, surgido durante la década de los años 1970 en Estados Unidos. La incorporación de elementos propios del entretenimiento a los géneros periodísticos, $\mathrm{y}$ en concreto, a los géneros informativos en televisión ha propiciado una nueva forma de elaborar las noticias que se 
emiten a diario. El papel jugado por las imágenes ha ido adoptando una mayor relevancia a la hora de elaborar noticias cada vez más llamativas para los espectadores y, por consiguiente, con una mayor capacidad para captar su atención. Por añadidura, el advenimiento de la sociedad de la información ha venido a acentuar el poder de las imágenes en todo tipo de soportes, lo que obliga al medio televisivo a competir con otros medios de comunicación en la captación de audiencias cada vez más fragmentadas.

La complejidad de los hechos informativos y el progreso de las tecnologías de la información ha dado lugar a la elaboración de piezas informativas en las que los códigos audiovisuales se relacionan en distinto grado y forma creando productos informativos con mensajes que requieren una mayor habilidad por parte de la audiencia para ser descodificados con eficiencia en relación a épocas pasadas. El análisis de la competencia mediática de los espectadores de televisión de principios del siglo XXI se ha abordado en una investigación llevada a cabo en el año 2010 en España. El estudio se inserta dentro de la llamada redundancy, que analiza el nivel de concordancia entre los elementos audiovisuales en los informativos de televisión y sus efectos en la comprensión y en el recuerdo de información por la audiencia de este medio de comunicación.

La investigación tiene por objetivo analizar el modo en que los consumidores de información televisiva asimilan los mensajes construidos en base a distintos grados de correspondencia entre el código icónico, el lingüístico y el sonoro. La investigación aporta nuevos datos sobre los efectos indirectos en la asimilación y retención de información relativa a imágenes de impacto y trata aspectos no abordados hasta la fecha por la doctrina como son el grado de coordinación entre elementos icónicos y verbales, la utilización de técnicas de recapitulación de información y la comprensión del mensaje.

El análisis del procesamiento de la información icónica se ha llevado a cabo por la doctrina desde la década de 1970 en relación al recuerdo de información. Los estudios practicados hasta la década de los años 1990 dieron como fruto la formulación de una serie de teorías que fueron tomadas como punto de partida para efectuar un nuevo análisis que actualizase los datos registrados en tiempos pasados en relación a la audiencia de televisión de finales de la década de los años 2000.

El análisis partió de dos hipótesis relativas al procesamiento del mensaje en televisión a partir de las cuales se desarrolló un experimento entre sesenta voluntarios. Por un lado se entendía que la coordinación entre los códigos lingüístico, icónico y sonoro aumentaba la comprensión y retención del mensaje informativo en el medio televisivo. Pero, por otro lado, se consideraba que podían existir fórmulas alternativas de comprensión y recuerdo del mensaje asociadas a otros niveles de coordinación entre códigos audiovisuales. El código icónico fue analizado en relación a dos tipos de imágenes particularmente relevantes en los informativos de televisión de finales de los años 2000: las imágenes impactantes y las imágenes llamativas de signo positivo y negativo. Estas últimas fueron una construcción teórica formulada en la investigación y analizadas de forma empírica por primera vez en España.

\section{Fuentes y metodología}

El estudio llevado a cabo en el año 2010 fue de naturaleza esencialmente cuantitativa aunque incorporó un análisis de tipo cualitativo en función de los objetivos de la in- 
vestigación. Esta consistió en la práctica de un experimento entre sesenta voluntarios de distinto sexo y diferentes perfiles socioeconómicos que constituyeron una muestra seleccionada de forma no probabilística. El muestreo fue de tipo estratificado y se empleó el método de selección de cuotas. La finalidad era escoger a una muestra de participantes lo más cercana posible a las características de la audiencia de informativos de televisión generalista de cuatro cadenas españolas de referencia: Televisión Española, Antena 3, Telecinco y Cuatro durante la temporada inmediatamente anterior al desarrollo del experimento -meses de septiembre de 2008 a julio de 2009-. La información sobre datos de audiencia y perfil de espectadores proporcionada por las cadenas de televisión citadas permitió moldear una muestra de participantes muy similar a la real. Los voluntarios procedieron de distintas comunidades autónomas (Madrid, Cataluña, Castilla-La Mancha y Principado de Asturias) y cumplieron los requisitos de formación académica, edad y clase social requeridos. La selección de participantes se llevó a cabo durante un período de tiempo de siete meses consecutivos del año 2010. Los resultados obtenidos forman parte de un sondeo de tipo puntual efectuado en el último año de la década de 2000.

Los sesenta voluntarios finalmente seleccionados respondieron a una encuesta de treinta y una preguntas abiertas, cerradas, semi-cerradas y en escala de valoración sobre distintas variables que interesaba analizar en relación al procesamiento de información audiovisual. Las preguntas versaron sobre el contenido de un informativo de televisión especialmente editado para la investigación, elaborado en dos versiones diferentes que incluyeron noticias comunes y alternativas que fueron mostradas a dos grupos de voluntarios. Se seleccionaron de forma estratificada dos series de treinta participantes que formaron respectivamente un grupo de control y un grupo experimental.

Las fuentes de la investigación fueron primarias y estuvieron constituidas por el informativo de televisión que comprendió diecinueve noticias no reales editadas con información gráfica y material de agencia. La redacción y edición de las noticias se elaboró en función de los fines de la investigación. La finalidad de este procedimiento era crear piezas que contuvieran una serie de variables susceptibles de ser analizadas de forma aislada o conjunta, según el caso, y evitar al mismo tiempo la contaminación informativa que podría darse en el caso de haber mostrado a los participantes un informativo emitido por una cadena de televisión de las cuatro tomadas como referencia. Se entiende que las noticias reales que los voluntarios podrían haber escuchado o visionado en otros medios de comunicación durante el desarrollo del experimento podrían interferir en el recuerdo y en la comprensión del mensaje a corto plazo, entendido este como el registrado en un plazo de tiempo comprendido entre veinticuatro horas y siete días tras el visionado del informativo.

\section{Imágenes de impacto y coordinación entre códigos audiovisuales}

Algunos autores que han tratado el tema de la coordinación entre los códigos audiovisuales en los informativos de televisión mencionan en sus estudios a las imágenes de naturaleza impactante que, según los resultados obtenidos, son capaces de influir de manera determinante en la retención del mensaje por la audiencia (Newhagen y Reeves, 1992: 25; Lang, Newhagen y Reeves, 1996: 460; Nabi, 1999: 292-320). 
No obstante, son pocos los expertos que se han atrevido a avanzar una definición de lo que se entiende por "imágenes impactantes". Posiblemente esto se deba a la dificultad en establecer una tipología exhaustiva de todas las clases de imágenes de impacto emotivo que pueden registrarse a lo largo de un informativo de televisión. La mayoría ha analizado el impacto de noticias en las que aparecen imágenes con una carga emotiva negativa, tales como imágenes de sucesos, catástrofes naturales o acontecimientos dramáticos en general. Los autores que más han analizado los efectos de las imágenes impactantes en el campo de la comprensión y el recuerdo de información han sido Lang, Newhagen y Reeves (1996: 460). Sus investigaciones han aportado datos muy valiosos respecto al recuerdo de la información que antecede y sucede a unas imágenes impactantes. Sin embargo, los autores tampoco ofrecen en sus estudios una definición de lo que se entiende por imágenes negativamente impactantes.

La doctrina considera distintos factores como la emotividad (Klijn, 2003: 124-134) o la intensidad visual (Zhou, 2004: 237) para distinguir a las imágenes impactantes de las no impactantes. Algunos autores emplean incluso otras expresiones como "imágenes perturbadoras" (Mundorf et al., 1990: 601-615) para referirse a esta noción sin especificar demasiado su naturaleza. En definitiva, puede afirmarse que no existe una definición ni unos criterios objetivos que permitan construir un concepto único de "imágenes impactantes". En la investigación llevada a cabo en España en el año 2010 se propuso un concepto de imágenes impactantes basado en los criterios concurrentes de la emotividad y de la negatividad. Se escogieron estos dos criterios porque se entiende que la emisión de las imágenes produce un impacto de naturaleza negativa susceptible de modificar el estado emocional previo de la audiencia. Se considera que solo las imágenes negativas son capaces de provocar un impacto en los espectadores con suficiente fuerza para incrementar el nivel de atención ${ }^{2}$ e influir -positiva o negativamente- en la comprensión y en el recuerdo de la información.

En la investigación se analizó con profundidad la influencia que ejerce el grado de coordinación entre códigos en la obtención de distintos niveles de recuerdo de información. Se pudo comprobar que este factor es determinante en el procesamiento de información difundida antes, durante y después de la emisión de unas imágenes de impacto. El grado de coordinación entre códigos constituye una nueva perspectiva de análisis del mensaje informativo en televisión -y del código icónico en particular- en el ámbito de la redundancy. En el pasado, los autores que han abordado el estudio de los efectos indirectos de las imágenes impactantes lo han hecho en relación al recuerdo y sin prácticamente tratar el grado de coordinación de los códigos audiovisuales. Solo

1 Las imágenes impactantes reciben distintas denominaciones en los estudios llevados a cabo por la doctrina. Las más comunes son "bad news pictures" (Zhou, 2004: 237) o "negative news pictures" (Newhagen y Reeves, 1992: 25).

2 En la investigación, el nivel de atención se midió en relación a la escala propuesta por Baggaley y Duck (1979: 92-93). Según los autores existen tres niveles de atención: alto -que genera un interés por las inferencias de la narración-, medio -que produce un interés por las inferencias de estímulos visuales o auditivos-, e inferior -que únicamente provoca un interés pasivo por el valor de novedad simple de las imágenes-. 
Zhou (2004: 237-256) abordó esta variable en un trabajo de investigación sobre distintos grados de intensidad visual incorporados a las noticias de televisión. Sin embargo, el autor analizó de forma independiente dos variables: el grado de coordinación entre códigos por un lado, y las imágenes con y sin impacto visual por otro.

Esta laguna en los estudios sobre el procesamiento de imágenes impactantes inspiró la posibilidad de analizar los efectos en el recuerdo provocados por distintos grados de coordinación entre códigos audiovisuales en presencia de imágenes de impacto negativo. Por consiguiente, en la investigación desarrollada en España se efectúa por primera vez un análisis relacional entre el factor "coordinación entre códigos audiovisuales" y el factor "imágenes de impacto negativo". Se observó que los espectadores expresaban peores cifras de recuerdo de información verbal durante la emisión de las imágenes de impacto cuando la correspondencia entre estas y la narración fue mayor. El efecto se suavizó una vez que este tipo de información icónica desapareció del plano. Tras la emisión de unas imágenes de impacto los espectadores tendieron a recordar mejor la información verbal, tanto en piezas con alto como con bajo grado de coordinación entre códigos, aunque el recuerdo fue algo mayor en noticias con una mayor correspondencia entre las imágenes y la narración.

Los resultados obtenidos aportan nuevos datos sobre el recuerdo de información emitida de forma previa, simultánea y posterior a unas imágenes de impacto en una pieza informativa. Es preciso señalar que la doctrina no se ha puesto de acuerdo sobre los efectos negativos o positivos que unas imágenes altamente emotivas pueden producir en el procesamiento del mensaje por la audiencia de televisión. De cualquier modo, el experimento llevado a cabo en esta ocasión continúa la línea de investigación propuesta por los expertos en los años 1990 pero añade una nueva perspectiva: el grado de coordinación entre códigos audiovisuales en noticias con imágenes impactantes.

Los resultados registrados podrían superar la teoría de la "doble codificación" que Robinson y Levy formularon en el año 1986 (Oliva y Sitjà, 2007: 170) en el sentido de que una alta concordancia entre códigos audiovisuales favorece un mejor recuerdo y comprensión de información verbal registrada antes y durante la emisión de las imágenes de impacto. En nuestro país no se han localizado estudios empíricos sobre este punto pero un sector doctrinal, recogiendo lo dispuesto por Robinson y Levy, afirma que, cuando existe una descoordinación entre el texto y las imágenes y además estas son de tipo emotivo, se dificulta la descodificación del contenido verbal del mensaje (Oliva y Sitjá, 2007: 170).

La respuesta de la audiencia también contradijo la teoría formulada por Newhagen y Reeves (1992: 25) en la década de 1990 ya que los autores aseguraron que era la información icónica -y no la verbal- la mejor recordada por la audiencia. Por el contrario, la teoría que se deriva de los datos obtenidos de la investigación desarrollada en la actualidad establece que la audiencia recuerda con mayor frecuencia y exactitud los datos del mensaje vehiculados a través del código lingüístico durante y después de la emisión de estímulos altamente emotivos como unas imágenes impactantes. Sin embargo, es preciso advertir que Newhagen y Reeves llevaron a cabo un estudio conjunto con la investigadora Annie Lang en el año 1996 que matizó lo afirmado cuatro 
años antes por los propios autores. En el estudio se reconoció que existían indicios de que los efectos negativos en el recuerdo de información provocados por la presencia de imágenes de impacto se dejaban sentir principalmente en el canal visual. Se dejó la puerta abierta a posteriores investigaciones que confirmasen ese extremo (Lang, Newhagen y Reeves, 1996: 475). Como se puede comprobar no existe unanimidad entre la doctrina respecto a qué tipo de información se recuerda peor o mejor en presencia de imágenes de impacto negativo.

En la investigación se estudió otro tipo de imágenes con menor capacidad para influir en el recuerdo de información en televisión. Se trata de las "imágenes llamativas" que al igual que las imágenes impactantes se basan en el criterio de la "emotividad". A diferencia de las imágenes impactantes que conllevan en todo caso una connotación negativa, las "imágenes llamativas" pueden ser de carácter positivo o negativo. Las teorías sobre este tipo de imágenes que se aportan en la investigación son originales en el sentido estricto del término, por cuanto la doctrina no ha emprendido aún estudios sobre esta variable. No obstante, los autores sí han demostrado un cierto interés por abordar el examen de otros tipos de imágenes emotivas además de las imágenes de impacto. Algunos autores iniciaron una línea de investigación sobre los efectos que distintos tipos de noticias con impacto visual negativo producen en el recuerdo del mensaje por la audiencia. A título de ejemplo, autores como Newhagen (1998: 265276) o Miller y Leshner (2007: 23-40) estudiaron la influencia en el recuerdo de noticias que provocaban miedo y desagrado en los espectadores.

En la investigación llevada a cabo en nuestro país se prefirió efectuar una primera aproximación a las denominadas "imágenes llamativas" que se asocian en la actualidad a informaciones de tipo anecdótico, sobre hechos extraordinarios o poco habituales que llaman la atención de los espectadores. La razón es que este tipo de piezas son cada vez más habituales y se incluyen a diario en las ediciones de los informativos de televisión de la mayoría de países occidentales. La tendencia a una mayor "espectacularización" de la información ha dado cabida a un mayor número de informaciones de este tipo en los noticiarios, además de las ya analizadas noticias con imágenes de impacto. Por ello, se decidió proceder al análisis de las "imágenes llamativas", siempre en función del grado de coordinación entre códigos audiovisuales.

Se consideran "imágenes llamativas" aquellas imágenes fijas o en movimiento que llaman la atención de los espectadores sin incidir de forma determinante en la comprensión y/o recuerdo del mensaje informativo al que van asociadas. En ningún caso interfieren o anulan el recuerdo o la comprensión del mensaje y su contenido puede ser de naturaleza negativa o positiva. A título meramente ilustrativo, las "imágenes llamativas positivas" serían: imágenes anecdóticas, de curiosidades, imágenes de celebraciones varias, logros deportivos y sucesos poco comunes o extraordinarios. En todo caso, el impacto que se causa en los sentimientos de la audiencia es percibido siempre como positivo. Por su parte, las "imágenes llamativas negativas" serían imágenes ilustrativas de hechos informativos, sucesos y otros fenómenos con consecuencias negativas (ej. llamaradas, truenos, impactos, etc.).

La ausencia de teorías y experimentos sobre este tipo de imágenes animó a realizar un análisis lo más completo posible que también abarcase el enfoque de la con- 
cordancia entre códigos. Así, se quiso analizar la influencia en el recuerdo de "imágenes llamativas" de distinto signo (positivas y negativas), los efectos provocados por una descoordinación creada con fines expresivos como los "encabalgamientos"3 $\mathrm{y}$, finalmente, el tipo de información (visual o verbal) recordada en mayor proporción por la audiencia a lo largo de las noticias.

Se comprobó que las imágenes llamativas favorecen el recuerdo de información global tanto en noticias con un alto grado de coordinación como en aquellas con un bajo grado de correspondencia entre códigos audiovisuales. También se pudo comprobar que se recuerda mejor la información verbal que la icónica en informaciones con cualquier grado de correspondencia entre las imágenes y la narración. En relación a las dos clases de "imágenes llamativas", el experimento deja pendiente la evaluación de imágenes positivas y negativas en presencia de un alto grado de coordinación entre códigos. Sí hubo ocasión de analizar el comportamiento de la audiencia en noticias elaboradas con un grado medio de coordinación. En ese sentido, puede afirmarse que los espectadores recordaron mejor la información visual transmitida a través de las "imágenes llamativas" de signo positivo.

En lo que respecta a la técnica del "encabalgamiento", esta no deja de ser una forma de descoordinación entre códigos audiovisuales. Por ello se decidió analizar sus efectos en el recuerdo de información elaborada mediante este tipo de imágenes. La técnica se reveló como ineficaz para mejorar el recuerdo de información. La audiencia recordó mejor los datos expresados en aquellas partes de la pieza en las que no se produjo el adelanto de las imágenes llamativas sobre la narración. Es decir que en esta ocasión, un grado más alto de coordinación entre códigos fue más eficaz para mejorar el recuerdo que uno más bajo.

Estos resultados comparados con los obtenidos en relación al recuerdo de información en noticias con imágenes impactantes y distinto grado de coordinación entre códigos, indican la existencia de diferencias en el procesamiento del mensaje en función del contenido emotivo que transmite el código icónico. Se recuerda que el mensaje elaborado con un menor grado de coordinación entre códigos y presencia de imágenes impactantes tiende a ser mejor recordado que aquel construido con una correspondencia más elevada entre las imágenes y la narración.

Finalmente, se puede concluir que las "imágenes llamativas" comparten con las impactantes la capacidad de elevar el grado de atención de la audiencia hasta un nivel superior donde los espectadores se centran en el contenido de la narración (Baggaley y Duck, 1979: 92-93). Sin embargo, no parece que posean entidad suficiente para orientar con preferencia el recuerdo de información hacia un código u otro -icónico o lingüístico- en noticias con distinto grado de coordinación.

${ }^{3}$ La técnica del "encabalgamiento" consiste en la anticipación de un código audiovisual en relación a otro durante un breve espacio de tiempo. Lo más habitual en los noticiarios de televisión es que la imagen se adelante a la narración en una pieza informativa. Los llamados "encabalgamientos" producen una descoordinación entre códigos de carácter puntual efectuada con fines expresivos. 


\section{El uso de imágenes de impacto en rótulos y titulares}

En la investigación que ahora se presenta se dio prioridad a la perspectiva de la coordinación entre códigos audiovisuales en el análisis de las variables objeto de estudio $\mathrm{y}$, entre ellas, las técnicas de recapitulación de información. En relación a estas, solo Son, Reese y Davie (1987: 207-216) efectuaron un cruce de variables como el realizado en el experimento de la investigación. Los autores sentaron las bases de una teoría según la cual las técnicas de recapitulación de información se muestran efectivas para mejorar el recuerdo de información en noticias con un grado alto de correspondencia entre códigos audiovisuales. Los autores solo analizaron el recuerdo y la comprensión registrados tras la inclusión o no de rótulos de texto en noticias con distinto grado de coordinación. Por aquel entonces -finales de la década de 1980- no se abordó el tratamiento de los titulares ni su vinculación con un grado concreto de coordinación entre códigos audiovisuales. El experimento llevado a cabo en el año 2010 reprodujo la observación de la variable "rótulos de texto" pero amplió el análisis a la variable "titulares" y además se observó la interacción de estos con el factor "coordinación entre códigos audiovisuales" durante la emisión de imágenes impactantes.

En relación a los titulares mostrados en el inicio de un informativo se descubrió que cuando se produce una descoordinación entre códigos, la audiencia insiste en recordar con preferencia la información de origen verbal, aunque el recuerdo ya no se centra tanto en los rótulos de texto sino que se dirige hacia otras partes de la noticia como, por ejemplo, la entradilla. La interacción de un alto grado de coordinación con otras variables con entidad para distraer la atención de los espectadores como pueden ser unas imágenes impactantes, también empeoró el recuerdo de datos concretos contenidos en los rótulos de los titulares.

En ausencia de otras variables, la audiencia puede recuperar información contenida en los rótulos de texto con facilidad pero encuentra mayores obstáculos cuando su atención se ve alterada por otros estímulos como unas imágenes de impacto. Los resultados son los primeros que se obtienen tras analizar la asociación entre los titulares de un informativo y el grado de coordinación entre códigos audiovisuales. Futuros estudios podrían confirmar o refutar los hallazgos de este experimento así como ampliar el estudio de los efectos provocados por otras variables como, por ejemplo, las imágenes de tipo llamativo.

Se observa que la presencia de imágenes impactantes, tanto en noticias como en titulares de un informativo, consigue modificar el procesamiento sistemático de información en piezas elaboradas con distintos grados de coordinación. En la investigación se comprobó que informaciones editadas con un bajo grado de concordancia entre el audio y el vídeo durante la emisión de imágenes altamente emotivas alcanzan índices de recuerdo y de comprensión más elevados que aquellas construidas con grados de correspondencia entre códigos más estrechos. Se estima como posible causa de este comportamiento el incremento del nivel de atención alcanzado por la audiencia al tener que realizar un sobresfuerzo para descodificar un mensaje diseñado con un bajo nivel de coordinación entre códigos audiovisuales y un mayor grado de complejidad originado por la presencia de imágenes impactantes.

En ese sentido se pronuncia un sector doctrinal que, a pesar de no tratar el grado de coordinación entre códigos, asegura que cuando se introducen imágenes de impacto ne- 
gativo la audiencia necesita destinar mayores recursos para procesar esa parte del mensaje (Newhagen y Reeves, 1992: 26-27) y que aumenta su nivel de atención (Lang, Newhagen y Reeves, 1996: 474). La atención de los espectadores se centraría en descodificar correctamente el código icónico en detrimento del lingüístico y del sonoro. Lo que afirma parte de la doctrina se inspira en el modelo de la "capacidad limitada para procesar mensajes mediáticos", conocida en términos científicos como LC3MP ideada por la investigadora Annie Lang. Según este modelo, el procesamiento de información es una acción limitada por la capacidad mental del ser humano (Lang, 2000: 47).

Gran parte de la doctrina acepta como válida esta propuesta. Desde los años 1970 los expertos en psicología cognitiva han venido afirmando la escasez de recursos de que dispone el ser humano para procesar información (Lang, 2000: 46-70). Este hecho es indiscutible desde el punto de vista biológico y psicológico. Muchas de las limitaciones detectadas en relación al recuerdo y a la comprensión de información televisiva se deben a las exigencias de tener que descodificar e interpretar un mensaje construido con una multiplicidad de códigos que se transmiten de forma simultánea e instantánea, sin posibilidad de relectura o reflexión sosegada como ocurre en los medios escritos. Autores como María del Mar Chicharro y José Carlos Rueda insisten en la especial dificultad para descodificar el mensaje televisivo debido a que se trata de un medio frío según la conocida clasificación de Marshall MacLuhan propuesta en el año 1964, que exige la activación de todos los sentidos del telespectador para obtener una información completa (Chicharro y Rueda, 2005: 343-344).

Posiblemente, el exceso de estímulos informativos sea un factor determinante para modificar la capacidad de la audiencia para procesar información audiovisual de forma eficaz. Se advierte que en la investigación practicada, la audiencia replicó el comportamiento relativo al uso de imágenes de impacto en noticias con saturación informativa provocada por una presencia acumulativa y excesiva de estímulos visuales, sonoros y auditivos. Un alto grado de coordinación no asegura tasas de recuerdo más altas ni tampoco una mejor comprensión del mensaje cuando interviene el factor "saturación informativa". Por el contrario, al igual que ocurre en el caso de las imágenes de impacto, el recuerdo y la comprensión son superiores cuanto menor es la correspondencia entre códigos audiovisuales.

Algunos autores manifestaron una opinión acerca de la forma en que actúan los estímulos altamente emotivos en el procesamiento de información por los televidentes (Heuer y Reisberg, 1990: 494-506; Brosius, 1993: 115). Brosius aseguraba que unas imágenes impactantes concentran la atención sobre lo que se emite en el momento de su emisión. Esto provocaría errores en el recuerdo de información contenida en otras partes de la noticia. El recuerdo de información procedente del código lingüístico se vería perjudicado de esta manera por imágenes de tipo emotivo (Brosius, 1993: 119). Ya se ha mencionado con anterioridad que el recuerdo de información verbal requiere un nivel de atención superior de la audiencia. Por ello, se acepta la hipótesis de que un potente estímulo visual pueda dirigir la atención de los espectadores hacia aspectos concretos de una historia contada en televisión. Sin embargo, no se comparte la opinión de que la información procedente del código lingüístico plantee necesariamente mayores problemas para ser recordada en comparación a otras fuentes de in- 
formación como asegura Brosius. Los resultados registrados en el experimento ponen en cuestión este aspecto de la teoría expresada por el autor ${ }^{4}$. Lo que en la investigación se sostiene es que en un mensaje con estímulos visuales con una alta carga emotiva los recursos para procesar información se distribuyen de forma distinta a la registrada por investigaciones anteriores.

\section{La comprensión de información en presencia de imágenes de impacto}

La comprensión del mensaje informativo no ha suscitado el mismo interés entre la doctrina que el recuerdo de datos en presencia de imágenes impactantes. En los estudios desarrollados desde los años 1970 no es frecuente localizar teorías estrictamente relacionadas con la comprensión de noticias con imágenes impactantes. Sí pueden citarse algunas investigaciones que analizan el error en el recuerdo de información como la realizada por Brosius en relación a noticias con y sin imágenes impactantes (Brosius, 1993: 105-124). Esta metodología es procedente por cuanto se entiende que existe una relación entre la información que se recuerda correctamente y la comprensión efectiva del mensaje. En la investigación llevada a cabo en el año 2010 se adoptó este método para detectar la capacidad de la audiencia para asimilar un mensaje elaborado con distintos grados de coordinación entre códigos audiovisuales y con presencia de imágenes de alto impacto emotivo. Se introdujo el concepto de información recordada con errores y sin errores porque se estima que la idea indica claramente si un espectador ha comprendido o no un determinado dato del mensaje que recibe.

Se pretendía descubrir qué tipo de información -icónica o lingüística- la audiencia es capaz de asimilar en mayor o menor medida antes, durante y después de la aparición en pantalla de estímulos visuales altamente emotivos. Para medir los efectos en la comprensión se recurrió al mencionado concepto de información recordada con y sin errores. Las investigaciones anteriores que han abordado el análisis de la comprensión del mensaje en función del canal -visual o auditivo- emplearon otros métodos de recogida de datos. Graber (1990: 134-155) recurrió al método cualitativo. Dirigió preguntas abiertas a los espectadores en las que se les pedía que se pronunciasen sobre el papel que habían ejercido las imágenes de las noticias que habían visto en la comprensión de datos del mensaje. En aquella ocasión, la audiencia estimó que el código icónico contribuye a mejorar el realismo de los hechos y la claridad del mensaje (Graber, 1990: 149-150). En esta investigación se prefirió evaluar la comprensión de información mediante la técnica de la encuesta a través de preguntas destinadas a recabar información recordada con ayuda y también sin ayuda. De esta forma se registraría de forma mucho más precisa el recuerdo de información recordada con y sin errores expresada por el código icónico y por el lingüístico respectivamente. Además, el empleo de preguntas semi-cerradas tenía por objetivo reducir el porcentaje de no respuesta habitualmente asociado a las preguntas de recuperación de información sin ayuda ${ }^{5}$.

4 En el experimento, la audiencia tendió a recordar con mayor facilidad los datos procedentes del código lingüístico cuando se analizaba la recepción de un mensaje elaborado con imágenes impactantes.

5 La información recordada con ayuda es la registrada mediante preguntas planteadas a los encuestados con algún tipo de ayuda o pista que facilite el recuerdo de datos. Por el contrario, 
Se analizó la información recordada incorrectamente antes, durante y después de la emisión de imágenes de impacto por espectadores que vieron una misma noticia editada en dos versiones con distinto grado de coordinación. Los resultados permitieron enunciar la teoría de que un bajo grado de coordinación no perjudica siempre la comprensión de información en presencia simultánea de imágenes de impacto como aseguraban Robinson y Levy (1986: 205). Sí se registraron mejores datos de comprensión de información global emitida antes y después de las imágenes de impacto en la versión con un grado más alto de correspondencia entre códigos. El grupo de voluntarios del experimento que vio la versión del informativo con la noticia coordinada en un mayor grado erró entre un 34\% y un 38,2\% menos el recuerdo de datos que se transmitieron antes y después de las imágenes impactantes respectivamente.

En relación al tipo de información mejor comprendida por los espectadores, se puede afirmar que el grado de coordinación constituye un factor relevante en la asimilación de datos del mensaje transmitido por distintos códigos audiovisuales. Un nivel más alto de correspondencia entre las imágenes y la narración permite obtener tasas más elevadas tanto de información verbal como icónica correctamente recordada antes y después de la aparición en pantalla de imágenes de alto impacto emotivo. Sin embargo, el patrón de comportamiento de la audiencia se invierte durante la emisión de imágenes de impacto.

Se comprobó que el grupo de voluntarios que había visto la versión con mayor grado de coordinación entre códigos erró un $62,5 \%$ menos el recuerdo de información verbal emitida antes del estímulo visual y un 35\% menos después de la emisión de las imágenes.

Las diferencias fueron mucho mayores para la información icónica recordada con posterioridad a los planos más emotivos de la noticia. El grupo que vio la versión con mayor grado de correspondencia entre códigos erró en una proporción tres veces menor que el que visionó la noticia con un menor acercamiento entre la narración verbal y las imágenes.

La información narrada de forma simultánea a la emisión de las imágenes impactantes fue comprendida exactamente en la misma medida por los integrantes del grupo experimental y por los de control. Un mayor grado de coordinación entre códigos durante la emisión de imágenes de impacto no determinó una mejora de la comprensión del mensaje. Los resultados del experimento estarían rebatiendo de nuevo la ya citada teoría de la "doble codificación” de Robinson y Levy (en Oliva y Sitjà, 2007: 170).

Las causas por las cuales la audiencia no recuerda peor los datos narrados durante la emisión de imágenes impactantes en piezas con un menor grado de correspondencia entre códigos audiovisuales podrían tener que ver con la forma en que la audiencia descodifica la información cuando se producen alteraciones en la exposición del mensaje en televisión. Según las teorías sobre la capacidad limitada de los espectadores para procesar mensajes audiovisuales (Wickens, 1984 en Drew y Grimes, 1987:

la información recordada sin ayuda es aquella recopilada de forma espontánea por los encuestados. Esta metodología es habitual en los estudios sobre recepción del mensaje informativo en televisión. 
452-453; Lang, 2000: 47) podría ocurrir que los espectadores se viesen obligados a elegir centrar su atención entre varios códigos cuando los estímulos a los que se les somete les exigen un esfuerzo excesivo para descodificar correctamente el mensaje informativo en su totalidad. Es posible que el hecho de alejar las imágenes más emotivas de los datos esenciales del mensaje en la versión con menor grado de coordinación global hiciera más fácil el proceso de comprensión de información procedente del código lingüístico.

También podría ocurrir que los espectadores tuviesen que elegir entre centrar su atención en el código icónico o en el lingüístico cuando un factor extra -la descoordinación entre códigos- se introduce en el proceso de descodificación del mensaje. En cierto modo se estarían activando mecanismos de defensa para lograr centrar la atención en el código que transmite los datos más relevantes del mensaje. En el experimento practicado lo esencial de la información se transmitió por vía oral en ambas versiones del informativo. Se presume que el esfuerzo realizado por los espectadores para atender al contenido del mensaje elevaría su atención a un nivel superior, compatible para efectuar un correcto procesamiento de la información verbal en aquellas partes del mensaje que requieren una mayor concentración. Durante la emisión de las imágenes de impacto, el nivel de atención alcanzado sería superior al que se conseguiría en noticias con un mayor grado de coordinación que posiblemente exijan a priori un menor grado de concentración.

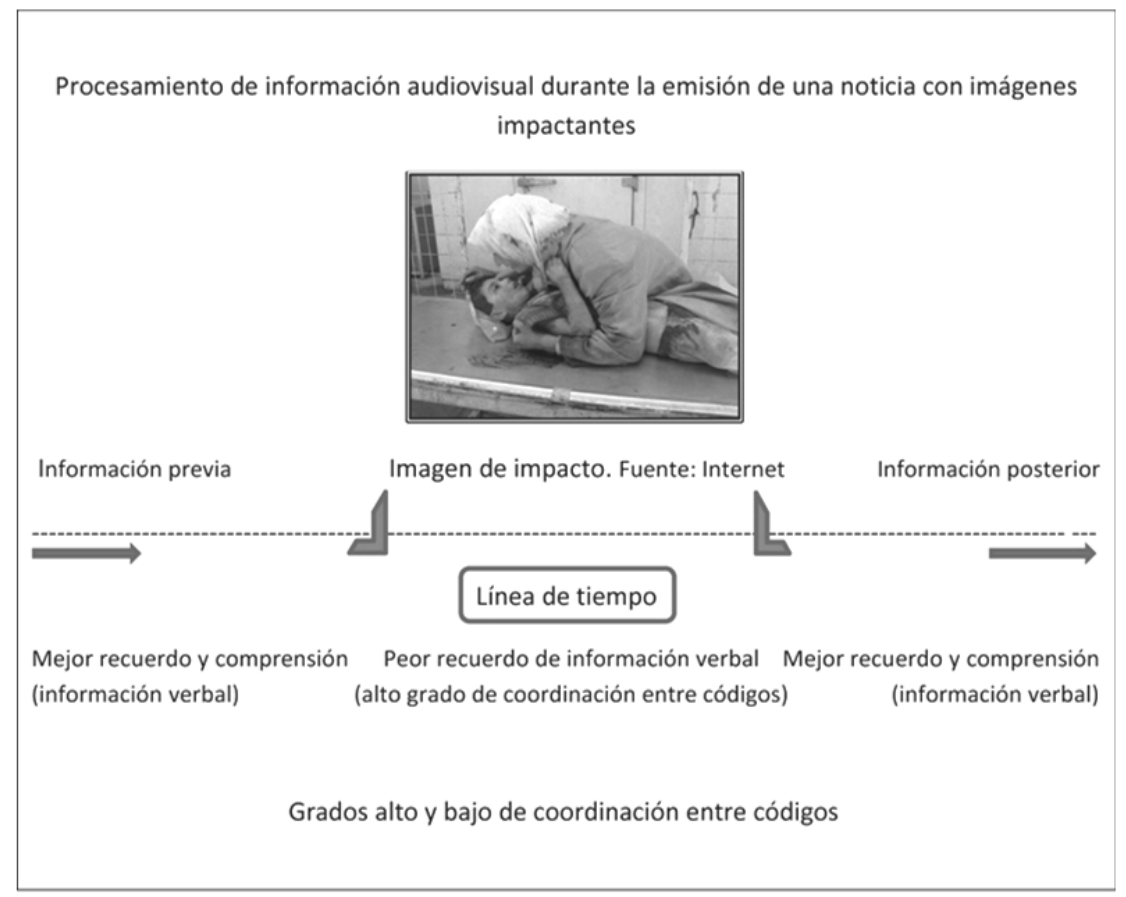

Gráfico no 1. Recuerdo y comprensión del mensaje en presencia de imágenes impactantes. Fuente: Elaboración propia 
Los resultados obtenidos permiten discutir las opiniones manifestadas por un sector doctrinal que afirma que en caso de conflicto entre el canal visual y el auditivo, la atención se dirige hacia el código icónico por ser este el que más rápido transmite significados semánticos y el que requiere un menor esfuerzo cognitivo (Drew y Grimes, 1987: 459). En las piezas analizadas en el experimento, las imágenes de impacto comunicaron un significado unívoco, por lo que se presume que su descodificación no requirió demasiado esfuerzo a los espectadores. Se entiende que en este caso el factor determinante de las diferencias en la comprensión de información no fue la naturaleza altamente emotiva de las imágenes visionadas sino la interacción de esta variable con un distinto grado de coordinación entre la narración visual y la oral.

\section{Conclusiones}

La investigación llevada a cabo desvela nuevas claves sobre el comportamiento de la audiencia de televisión cuando debe procesar un mensaje informativo elaborado con distintos grados de coordinación entre códigos audiovisuales y diversos tipos de imágenes de naturaleza emotiva.

Los resultados del experimento practicado demostraron que un grado alto de correspondencia entre el código icónico y el lingüístico favorece el recuerdo y la comprensión de información en un número estimable de noticias. Sin embargo, la eficacia se reduce notablemente cuando en el mensaje se introducen factores con capacidad para modificar el nivel de atención de los espectadores. Entre estos factores se incluyen los estímulos de naturaleza altamente emotiva como las imágenes de impacto. Por otro lado, se demostró que informaciones con un grado más bajo de coordinación entre la narración y las imágenes de naturaleza impactante eran mejor recordadas que otras con un grado de concordancia mayor, tanto en noticias como en titulares de un informativo.

Los espectadores de principio del siglo XXI parecen tener mayor facilidad para recordar información verbal antes y después de la emisión de unas imágenes de impacto. No obstante el patrón de comportamiento se ve modificado cuando se introduce un grado más alto de concordancia entre códigos audiovisuales. En ese caso, el recuerdo de datos transmitidos a través del canal oral empeora. El mejor recuerdo de información verbal -en relación a la icónica- se produce tras la emisión de las imágenes de impacto con independencia del grado de coordinación entre los códigos audiovisuales.

El uso de imágenes llamativas resultó ser positivo para el recuerdo de información audiovisual en noticias con un grado alto y bajo de coordinación entre códigos. En noticias que incluyen este tipo de imágenes la audiencia insistió de nuevo en recordar mejor la información verbal que la icónica.

En relación a las técnicas de recapitulación de información y, en particular, a los titulares del inicio de un programa de noticias, el experimento registró nuevos datos relativos a la influencia en el recuerdo de distintos grados de coordinación entre la narración, los rótulos y las imágenes de impacto. En la investigación se llegó a la conclusión de que la retención de información es eficaz cuando se mantiene un alto grado de coordinación entre códigos audiovisuales durante la emisión de los titulares. Sin embargo, la introducción de imágenes impactantes en los titulares altera el procesa- 
miento de información verbal contenida en los rótulos de texto. En ese caso se registra un peor recuerdo de datos transmitidos a través de esa manifestación textual del código lingüístico, aun cuando en los titulares se da un alto grado de coordinación entre códigos.

Como novedad, la investigación aporta datos respecto a la comprensión de información en noticias con imágenes impactantes, un aspecto hasta la fecha no abordado por la doctrina. Al igual que ocurre con el recuerdo, la presencia del factor "imágenes impactantes" marca diferencias en la comprensión de datos del mensaje en función del grado de coordinación entre códigos audiovisuales. Las piezas elaboradas con una vinculación más fuerte entre las imágenes y la narración sólo favorecieron la obtención de contestaciones más acertadas de datos narrados verbalmente antes y después de la emisión de las imágenes de impacto pero no durante su emisión en pantalla. Los resultados de la encuesta practicada entre sesenta voluntarios demostraron que la comprensión de información verbal no mejoraba al introducir un grado más alto de correspondencia entre las imágenes de impacto y la narración simultánea. No se detectaron diferencias entre espectadores que vieron unos mismos hechos expresados con un grado más o menos alto de correspondencia entre la narración y las imágenes impactantes ya que en ambos casos el porcentaje de error en el recuerdo de información verbal ascendió a $10 \%$.

La investigación actualiza resultados sobre el procesamiento del mensaje informativo por la audiencia de televisión en presencia de imágenes de naturaleza emotiva, como las imágenes de impacto o las llamativas. Los resultados obtenidos indican que la audiencia de finales de la década de 2000 ha modificado la forma en que asimila y retiene información procedente de un mensaje elaborado con distintos grados de correspondencia entre códigos audiovisuales. Este factor es determinante en el procesamiento de datos de carácter audiovisual tanto en lo que se refiere al recuerdo como a la comprensión de información. La respuesta de la audiencia indica la posibilidad de que hayan quedado superadas algunas teorías formuladas por los expertos en el pasado en relación a las imágenes impactantes como las relativas al mejor recuerdo de la información icónica o la dificultad en procesar información contenida en piezas con imágenes impactantes y un bajo grado de coordinación entre códigos.

De cualquier modo, la investigación ha intentado sentar nuevas bases de estudio del mensaje informativo en el medio televisivo, así como de los efectos indirectos en la comprensión y retención de datos por la audiencia desde la perspectiva de los códigos audiovisuales. El estudio llevado a término abre la puerta a nuevas líneas de investigación del mensaje informativo que requieren un análisis más profundo de los distintos aspectos tratados a lo largo de la investigación como la introducción de las imágenes llamativas de distinto signo y los efectos en la comprensión de imágenes de impacto emotivo.

\section{Referencias bibliográficas}

BAGGALEY, Jon P. y DUCK, Steve W. (1979): Análisis del mensaje televisivo. Barcelona, Gustavo Gili D.L. 
BROSIUS, Hans-Bernd (1993): "The effects of emotional pictures in television news", en Communication Research, Vol. 20, $\mathrm{n}^{\mathrm{o}}$ 1. [s.1.], SAGE Publications, pp. 105-124.

CHICHARRO, María del Mar y RUEDA, José Carlos (2005): Imágenes y palabras. Madrid, Centro de Investigaciones Sociológicas. Siglo XXI de España Editores S.A.

DREW, Dan G. y GRIMES, Thomas (1987): "Audio-visual Redundancy and Tv news recall", en Communication Research, Vol. 14, no 4. [s.1.], SAGE Publications, pp. 452-461.

GRABER, Doris (1990): "Seeing is remembering: how visuals contribute to learning from Television News, en Journal of Communication, Vol. 40, $\mathrm{n}^{\circ} 3$. Austin (Texas), International Communication Association, pp. 134-155.

HEUER, Friderike y REISBERG, Daniel (1990): "Vivid memories of emotional events: the accuracy of remembered minutiae", en Memory and Cognition, Vol. 18, $\mathrm{n}^{\circ}$ 5. [s.1.], Psychonomic Society, pp. 494-506.

KLIJN, Marlies E. (2003): “Attention-Getting and Comprehension-Raising attributes in visuals in dutch and American, public and private television news about violence", en Journal of Broadcasting \& Electronic Media, Vol. 47, n 1. [s.1.], Broadcast Education Association, pp. 124-144.

LANG, Annie (2000): "The limited capacity model of mediated message processing", en Journal of Communication, Vol. 50, $\mathrm{n}^{\mathrm{o}} 1$. Austin (Texas), International Communication Association, pp. 46-70.

LANG, Annie; NEWHAGEN, John y REEVES, Byron (1996): "Negative video as structure: emotion, attention, capacity and memory", en Journal of Broadcasting \& Electronic Media, Vol. 40, n ${ }^{\circ}$ 4. [s.1.], Broadcast Education Association, pp. 460477.

MILLER, Andrea y LESHNER Glenn (2007): "How viewers process live, breaking and emotional news", en Media Psychology, Vol. 10, $\mathrm{n}^{\circ}$ 1. [s.1.], Routledge, pp. 23-40.

MUNDORF, Norbert; DREW, Dan; ZILLMANN, Dolf y WEAVER, James (1990): "Effects of disturbing news on recall of subsequently presented news", en Communication Research, Vol. 17, $\mathrm{n}^{\circ}$ 5. [s.1.], SAGE Publications, pp. 601-615.

NABI, Robin L. (1999): “A cognitive-functional model for the effects of discrete negative emotions on information processing, attitude change and recall", en Communication Theory, Vol. 9, $\mathrm{n}^{\mathrm{o}}$ 3. [s.1.], International Communication Association, pp. 292-320.

NEWHAGEN, John E. y REEVES, Byron (1992): “The evening's bad news: effects of compelling negative television news images on memory", en Journal of Communication, Vol. $42, \mathrm{n}^{\circ} 2$. Austin (Texas), International Communication Association, pp. $25-41$. 
NEWHAGEN, John E. (1998): "TV news images that induce anger, fear and disgust: effects on approach-avoidance and memory", en Journal of Broadcasting \& Electronic Media, Vol. 42, no 2. [s.1.], Broadcast Education Association, pp. 265-276.

OLIVA, Llucía y SITJÀ, Xavier (2007): Las noticias en radio y televisión. Periodismo audiovisual en el siglo XXI. Barcelona, Omega.

ROBINSON John P. y LEVY, Mark R. (1986): The main source: learning from television news. California, SAGE Publications.

SON, Jinok; REESE, Stephen D. y DAVIE, William R. (1987): "Effects of visualverbal redundancy and recaps on television news learning", en Journal of Broadcasting \& Electronic Media, Vol. 31, $\mathrm{n}^{\mathrm{o}}$ 2. [s.1.], Broadcast Education Association, pp. 207-216.

ZHOU, Shuhua (2004): "Effects of visual intensity and audiovisual redundancy in bad news", en Media Psychology, Vol. 6, n 3. [s.1.], Routledge, pp. 237-256. 